\title{
Liver Damage in Rabbits from Administration of a Single Dose of Gram-negative Endotoxin
}

\author{
ARTURO J. ABALLI, GUNGOR KARAYALCIN, FERNANDO COSTALES, ISADORE \\ GUBERNICK, AND PHILIP LANZKOWSKY ${ }^{(37)}$ \\ Department of Pediatrics and Laboratories of the Long Island Jewish-Hillside Medical Center; Queens Hospital \\ Center Affiliation; and the School of Medicine of the Health Sciences Center of the State University of New York at
} Stony Brook, New Hyde Park, New York, USA

\section{Summary}

The present experiments were undertaken to study the effect of a preparatory dose of gram-negative endotoxin on the liver. Sixteen adult male New Zealand rabbits had initial liver biopsies, blood chemistries, and coagulation studies and were then divided into two groups: group I, consisting of 10 animals, received $50 \mu \mathrm{g} / \mathrm{kg}$ endotoxin from Escherichia coli $0111 \mathrm{~B} 4$; group II, consisting of six animals, served as controls and received no endotoxin. In group I all animals developed increased levels of lactic dehydrogenase (LDH) isoenzyme 5 and SGOT and decreased serum albumin levels. $A$ rise in the level of SGPT and $5^{\prime}$-nucleotidase occurred in most rabbits. LDH isoenzyme 5 values increased from $3.6 \pm 5.83 \mathrm{mU} / \mathrm{ml}$ before to $180.4 \pm 142.11 \mathrm{mU} / \mathrm{ml}$ after endotoxin $(P<0.005)$. SGOT rose from $28.90 \pm 8.87 \mathrm{mU} / \mathrm{ml}$ to $241.10 \pm 104.76 \mathrm{mU} / \mathrm{ml}(P$ $<0.001)$. Serum albumin levels decreased from $3.78 \pm 0.31 \mathrm{~g} /$ dl to $3.21 \pm 0.32 \mathrm{~g} / \mathrm{dl}(P<0.001)$. SGPT initially showed a level of $41.00 \pm 6.97 \mathrm{mU} / \mathrm{ml}$ and this rose to $94.40 \pm 19.60$ $\mathrm{mU} / \mathrm{ml}(P<0.001) .5^{\prime}$-Nucleotidase rose from $1.48 \pm 0.69$ $\mathrm{mU} / \mathrm{ml}$ to $6.01 \pm 4.51 \mathrm{mU} / \mathrm{ml}(P<0.01)$. The animals also had changes in coagulation tests with a decrease in factors II and V. Factor II was $77.4 \pm 11.82 \%$ before and decreased to 38.70 $\pm 7.47 \%$ after endotoxin $(P<0.001)$. Factor $V$ values were $95.00 \pm 9.04 \%$ before and $50.6 \pm 7.5 \%$ after endotoxin $(P<$ $0.001)$. Changes in fibrinogen and factor VIII were not significant. Split products of fibrinogen showed a slight increase. Definite hepatic necrosis consisting of scattered patchy areas of variable size and severity was found in 7 of the 10 animals. In many of these areas of necrosis a polymorphonuclear leukocyte reaction and few small thrombi were detectable. The liver biopsies performed before endotoxin administration failed to show any evidence of hepatic involvement. Group II control animals showed no indications of abnormal liver function and no evidence of hepatic necrosis. These studies indicate that significant hepatic changes occur after the administration of a single dose of endotoxin given in preparation for the Shwartzman reaction.

\section{Speculation}

In rabbits significant liver damage has been demonstrated after an injection of gram-negative endotoxin. The dose of endotoxin employed was similar to that frequently used to prepare animals for the Shwartzman reaction. This liver damage was demonstrated to occur at a time when the provocative dose of endotoxin is usually given. In view of the role of the liver in replacing consumed clotting factors and in clearing thrombi, it is suggested that disturbed liver functions plays an important role in predisposing to disseminated intravascular coagulation (DIC), which is an integral part of the Shwartzman reaction.

Gram-negative endotoxin produces a wide variety of disorders in different animals $(5,16,22)$. Several investigators have documented abnormalities in liver function tests $(2,13,18,23$, $25,27)$ and others have reported diffuse necrotic lesions in the liver $(11,14,20,21,20)$. Most workers have not attached much significance to these findings. Since the hepatic pathology may explain other important disturbances produced by endotoxin, hepatic function was studied in greater detail following a preparatory dose of 0111-B4 E. coli endotoxin before the provocative dose was administered.

\section{MATERIALS AND METHODS}

Sixteen adult male New Zealand rabbits weighing between 2800 and $3300 \mathrm{~g}$ were studied between May 29 and October 11, 1975. All the animals had baseline blood studies, liver biopsies, and repeated blood studies $24 \mathrm{hr}$ thereafter. The animals were then divided into two groups: group I, consisting of 10 animals given endotoxin immediately after the liver biopsy, and group II, consisting of six animals serving as controls and not given endotoxin.

The animals were prepared in the following way. They were anesthetized using $3 \mathrm{mg} / \mathrm{kg}$ sodium thiopental intravenously and then immobilized. The skin of the neck was washed with Phisohex, sterilized with Betadine, and infilitrated with $2 \%$ Xylocaine. A horizontal incision was made on one side of the neck and the external jugular vein was isolated by blunt dissection and catheterized with a no. 5 polyvinyl feeding catheter. The catheter was fixed in position with silk and the wound repaired with interrupted sutures. This procedure permitted blood to be obtained for liver function tests, hematologic and coagulation studies, and for split products of fibrinogen in a satisfactory manner. Liver biopsies were performed by exposing the right lobe of the liver through a paramedian incision. A disposable liver biopsy needle (Travenol, Deerfield, IL) was used to obtain the biopsy.

After these baseline blood samples were obtained, $50 \mu \mathrm{g} / \mathrm{kg}$ 0111-B4 bovine type gram-negative endotoxin (Difco, Detroit, MI) were dissolved in $5 \mathrm{ml}$ saline and given in $1 \mathrm{~min}$ to the group I animals. Following this, the rabbits were fed ad libitum for the next $24 \mathrm{hr}$. After that time blood samples were again obtained and the animals were killed.

Blood chemistries were done on the rabbit serum using an AutoAnalyzer (Technicon, Tarrytown, NY). SGPT was performed by the method of Amador- and Wacker (3), lactic dehydrogenase isoenzymes by the use of Pol-E-Strat, as described by Hoffman (17), and 5'-nucleotidase by the method of Belfield et al. (4). Blood counts were performed on EDTA blood by a mechanical automated procedure (Coulter Electronics, Hialeah, FL). Coagulation studies included nonactivated partial time by the method of Langdell et al. thromboplastin (19), prothrombin time by that of Shapiro et al. (26), factor V by the method of Wolff (29), and factor II by the modified method of Owren (28). Factor VIII was assayed by the technique of Langdell et al. (19). Results were obtained in percent- 
age from a normal curve constructed from the results of mixed plasmas from three normal rabbits. Fibrinogen was determined by the biuret method. Platelets were counted by phase microscopy with the method of Brecher and Cronkite (6). Split products of fibrinogen were investigated by the staphylococcal clumping test (15).

After the animals were killed the organs were fixed in $10 \%$ buffered formalin. Histologic slides of liver, kidney, spleen, and lungs were stained with hematoxylin and eosin and with phosphotungstic acid hematoxylin for fibrin and examined under light microscopy (Figs. 1-3).

The test results were analyzed statistically. $P$ values were derived from results of the $t$ test obtained for various results. Liver function tests were considered abnormal if values deviated more than 2 SD from the normal means.

\section{RESULTS}

\section{BLOOD CHEMISTRIES}

Changes in blood chemistry values before and $24 \mathrm{hr}$ after endotoxin are shown in Table 1. There were significant increases in the mean values of SGOT, total protein, serum albumin, cholesterol, SGPT, 5'-nucleotidase, and lactic dehydrogenase isoenzyme 5. No significant differences were observed in total lactic dehydrogenase, alkaline phosphatase, and bilirubin levels. Review of differences in individual animals between initial values and those after endotoxin revealed that every animal had a significant increase in lactic dehydrogenase isoenzyme 5 and SGOT, and a decrease in total protein and serum albumin. Six animals had elevation in the SGPT level and seven animals had elevation in 5'-nucleotidase level. These tests and a decrease in serum albumin indicate hepatic dysfunction. Abnormal results were at least 2 SD from the mean of the control animals. There were no significant differences in blood chemistries before and after liver biopsy in the control animals not given endotoxin (Table 2). There were no abnormal liver function tests in specimens obtained before endotoxin administration in any of the animals.

\section{COAGULATION TESTS}

There were significant changes in several coagulation tests in animals given endotoxin (Table 3 ). Factors II and V were significantly decreased in all animals after endotoxin injection, whereas factor VIII and fibrinogen levels were not significantly altered after endotoxin. A marked drop in platelet count was observed in all animals after endotoxin. Staphylococcal clumping showed slight increase in all animals after endotoxin. The mean levels of the titer of staphylococcal clumping after endotoxin were much lower than we have usually seen during full blown disseminated intravascular coagulation (1).

There was no significant changes in any of the coagulation factors before and after liver biopsy in the control animals not given endotoxin.

\section{PATHOLOGIC FINDINGS}

Results of the pathologic findings are tabulated in Table 4. Liver biopsies performed in all animals in group I did not reveal any necrotic lesions but one liver revealed inflammatory reaction around bile ducts and one had fatty infiltration. Of the 10 animals given endotoxin, 7 developed necrotic lesions in the liver. Lesions varied considerably in size and severity. Most of them only involved portions of a liver lobule and the most extensive affected adjacent lobules. Nuclei were either smudgy, pyknotic, or entirely absent. In some areas most hepatic cells had been completely destroyed. A polymorphonuclear leukocyte reaction was usually present in areas of necrosis. The

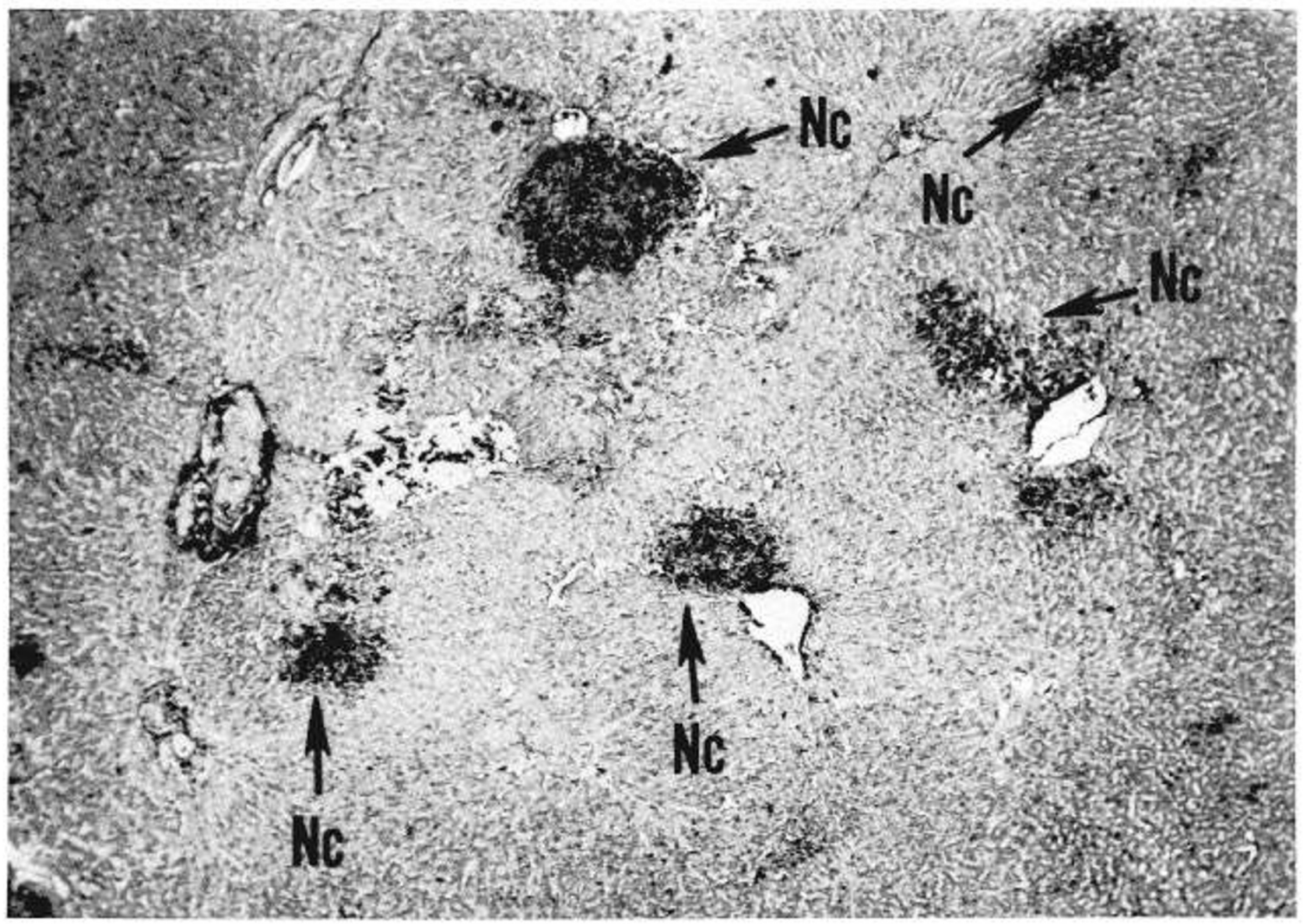

Fig. 1. Section of liver showing patchy areas of necrosis $(\mathrm{Nc})$ with haphazard distribution (hematoxylin and eosin stain; magnification, $\times 100$ before reproduction). 


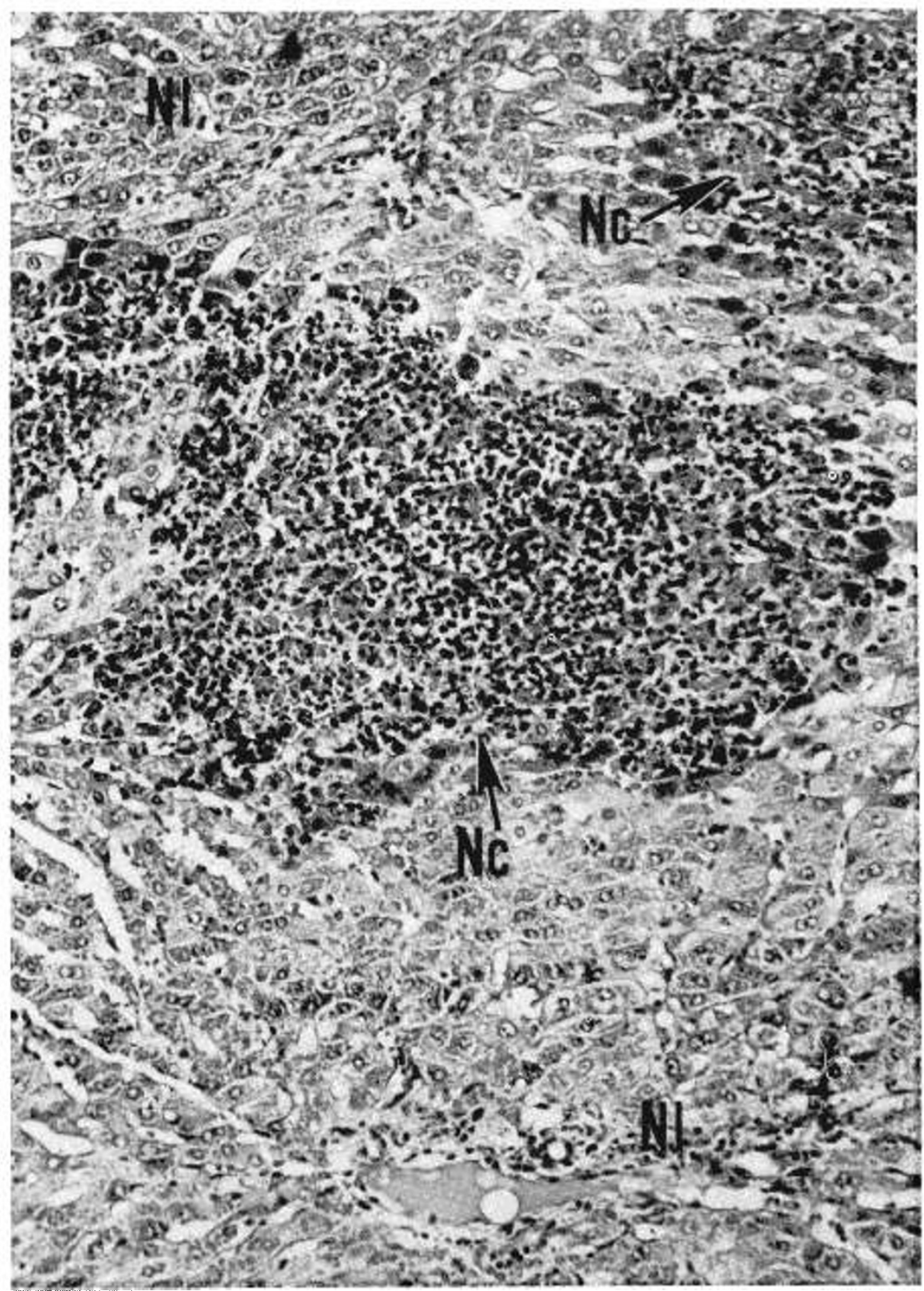

Fig. 2. Section of liver showing foci of necrosis $(\mathrm{Nc})$ and inflammatory exudate (hematoxylin and eosin stain; magnification, $\times 400$ before reproduction).

Table 1. Mean and SD of blood chemistry values before and $24 \mathrm{hr}$ after endotoxin in 10 animals (group I)

\begin{tabular}{lcccc}
\hline \multicolumn{1}{c}{ Values } & Before & After & $t$ & $P$ value \\
\hline SGOT, mU/ml & $28.90 \pm 9.87$ & $241.10 \pm 104.76$ & 6.053 & $<0.001$ \\
LDH, mU/ml & $354.40 \pm 76.26$ & $400.50 \pm 152.22$ & 0.812 & NS \\
Alkaline phosphatase, $\mathrm{mU} / \mathrm{ml}$ & $102.50 \pm 36.18$ & $154.30 \pm 117.24$ & 1.266 & $\mathrm{NS}$ \\
Bilirubin, mg/dl & $0.32 \pm 0.33$ & $0.27 \pm 0.08$ & 0.050 & $\mathrm{NS}$ \\
Total protein, g/dl & $6.18 \pm 0.44$ & $5.43 \pm 0.60$ & 3.048 & $<0.01$ \\
Albumin, g/dl & $3.78 \pm 0.31$ & $3.21 \pm 0.32$ & 3.880 & $<0.001$ \\
Cholesterol, mg/dl & $50 \pm 14$ & $110 \pm 54$ & 3.522 & $<0.005$ \\
SGPT, mU/ml & $41.00 \pm 6.97$ & $98.40 \pm 19.60$ & 19.597 & $<0.001$ \\
5' Nucleotidase, $\mathrm{mU} / \mathrm{ml}$ & $1.48 \pm 0.69$ & $6.01 \pm 4.51$ & 2.976 & $<0.01$ \\
LDH ISO-5, $\mathrm{mU} / \mathrm{ml}$ & $3.6 \pm 5.83$ & $180.40 \pm 142.11$ & 3.900 & $<0.005$ \\
\hline
\end{tabular}

mildest lesions consisted of cell shrinkage with eosinophilic cytoplasm and some nuclear changes. Fibrin thrombi were seen in three of seven animals with liver necrosis. They were always observed within or adjacent to necrotic areas. Renal thromboembolic lesions were seen in only two animals, one of which had extensive symmetrical cortical necrosis. The latter animal also had an occasional thrombus in the lung. None of the control animals in group II revealed liver necrosis on liver biopsy or at autopsy. One of these animals showed evidence of parasitic infestation on liver biopsy, with inflammatory changes around 


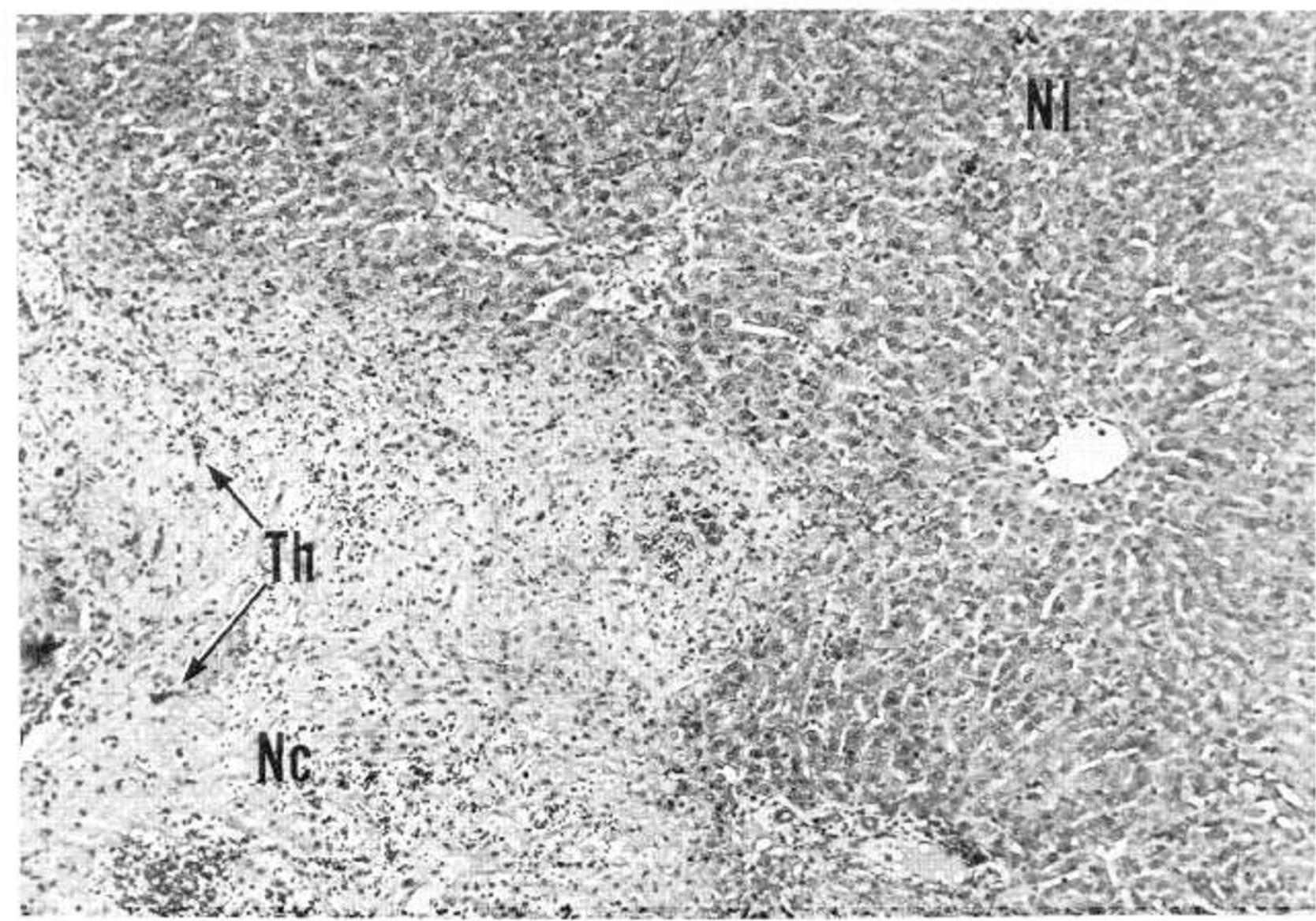

Fig. 3. Large confluent area of necrosis $(\mathrm{Nc})$ and small sinusoidal thrombi $(\mathrm{Th})$ contrasting with normal liver tissue (phosphotungstic acid hematoxylin stain; magnification, $\times 250$ before reproduction).

Table 2. Mean and SD of blood chemistry values before and $24 \mathrm{hr}$ after liver biopsy in six control animals not given endotoxin (group II)

\begin{tabular}{|c|c|c|c|c|}
\hline Values & Before & After & $t$ & $P$ value \\
\hline $\mathrm{SGOT}, \mathrm{mU} / \mathrm{ml}$ & $44.33 \pm 20.94$ & $49.32 \pm 18.25$ & 0.402 & NS \\
\hline $\mathrm{LDH}, \mathrm{mU} / \mathrm{ml}$ & $377.83 \pm 97.80$ & $283.5 \pm 88.86$ & 1.596 & NS \\
\hline Alkaline phosphatase, $\mathrm{mU} / \mathrm{ml}$ & $85.83 \pm 42.33$ & $66.17 \pm 29.98$ & 0.857 & NS \\
\hline Bilirubin, $\mathrm{mg} / \mathrm{dl}$ & $0.3 \pm 0.00$ & $0.28 \pm 0.03$ & 0.017 & NS \\
\hline Total protein, $\mathrm{g} / \mathrm{dl}$ & $5.97 \pm 0.61$ & $5.78 \pm 0.84$ & 0.396 & NS \\
\hline Albumin, $\mathrm{g} / \mathrm{dl}$ & $3.87 \pm 0.60$ & $3.42 \pm 0.49$ & 1.308 & NS \\
\hline Cholesterol, mg/dl & $54 \pm 8.3$ & $62 \pm 8.9$ & 0.157 & NS \\
\hline $\mathrm{SGPT}, \mathrm{mU} / \mathrm{ml}$ & $52.50 \pm 22.34$ & $66.17 \pm 44.72$ & 0.611 & NS \\
\hline $5^{\prime}$-Nucleotidase, $\mathrm{mU} / \mathrm{ml}$ & $2.62 \pm 0.78$ & $2.42 \pm 1.44$ & 0.272 & NS \\
\hline $\mathrm{LDH}$ ISO- $5, \mathrm{mU} / \mathrm{ml}$ & $1.13 \pm 1.64$ & $0.50 \pm 1.12$ & 0.713 & NS \\
\hline
\end{tabular}

Table 3. Mean and SD of coagulation tests before and $24 \mathrm{hr}$ after endotoxin in 10 animals (group I)

\begin{tabular}{lcccc}
\hline \multicolumn{1}{c}{ Values } & Before & After & $t$ & $P$ value \\
\hline PT (sec) & $7.43 \pm 0.36$ & $7.92 \pm 0.62$ & 2.076 & NS \\
PTT (sec) & $39.4 \pm 9.50$ & $58.40 \pm 8.48$ & 4.477 & $<0.001$ \\
Factor II $(\%)$ & $77.4 \pm 11.82$ & $38.70 \pm 7.47$ & 8.304 & $<0.001$ \\
Factor V (\%) & $95.00 \pm 9.04$ & $50.60 \pm 17.5$ & 6.764 & $<0.001$ \\
Factor VIII $(\%)$ & $91.00 \pm 38.9$ & $73.00 \pm 30.00$ & 1.154 & NS \\
Fibrinogen $(\mathrm{mg} / \mathrm{dl})$ & $306.00 \pm 54.0$ & $236.00 \pm 76.00$ & 2.180 & NS \\
Platelets, $\mathrm{mm}^{3}\left(\times 10^{3}\right)$ & $445 \pm 81$ & $155 \pm 98$ & 6.855 & $<0.001$ \\
Staph clumping titer & $1: 19$ & $1: 61$ & & \\
\hline
\end{tabular}

portal spaces. Autopsy of the rabbit showed periportal inflammatory lesions and a small granulomatous lesion in the lungs. One rabbit had discrete pulmonary granulomas at autopsy.

\section{DISCUSSION}

This study has shown a consistent increase in the level of several serum enzymes (SGOT, and SGPT, LDH isoenzyme 5) after initial injection of endotoxin to rabbits. Similar findings have been reported by others in mice, dogs, and cattle $(2,13$, $18,20,23,25,27)$. In some of those studies, a progressive increase of these alterations with time was demonstrated and maximum levels were observed after 7-24 hr $(13,20,23)$. The consistency of positive findings in our investigation may be due to the fact that blood samples were regularly obtained $24 \mathrm{hr}$ 
Table 4. Pathologic findings ${ }^{1}$

\begin{tabular}{|c|c|c|c|c|c|c|c|}
\hline & \multirow[b]{3}{*}{ Animal no. } & \multirow[b]{3}{*}{ Liver biopsy } & \multicolumn{5}{|c|}{ Autopsy } \\
\hline & & & \multicolumn{3}{|c|}{ Liver } & \multirow[b]{2}{*}{ Lungs } & \multirow[b]{2}{*}{ Kidneys } \\
\hline & & & Necrosis & Thrombi & Other & & \\
\hline \multicolumn{8}{|c|}{ ET } \\
\hline & 1 & Infl. React. & Mild & 0 & Infl. React. & 0 & 0 \\
\hline & 2 & 0 & Severe & 0 & 0 & 0 & 0 \\
\hline & 3 & 0 & 0 & 0 & 0 & 0 & 0 \\
\hline & 4 & 0 & Massive & + & 0 & 0 & Thrombi \\
\hline & 5 & 0 & Severe & 0 & 0 & 0 & 0 \\
\hline & 6 & 0 & 0 & 0 & 0 & 0 & 0 \\
\hline & 7 & 0 & Severe & + & 0 & Thrombi & $\mathrm{SCN}$ \\
\hline & 8 & Fat. Inf. & 0 & 0 & Fat. Inf. & 0 & 0 \\
\hline & 9 & 0 & Severe & + & 0 & 0 & 0 \\
\hline & 10 & 0 & Mild & 0 & 0 & 0 & 0 \\
\hline \multicolumn{8}{|l|}{$\mathrm{C}$} \\
\hline & $\begin{array}{l}1 \\
2\end{array}$ & $\begin{array}{l}0 \\
0\end{array}$ & $\begin{array}{l}0 \\
0\end{array}$ & $\begin{array}{l}0 \\
0\end{array}$ & 0 & $\begin{array}{c}0 \\
\text { Gran }\end{array}$ & 0 \\
\hline & $\begin{array}{l}2 \\
3\end{array}$ & $\begin{array}{l}0 \\
0\end{array}$ & $\begin{array}{l}0 \\
0\end{array}$ & 0 & $\begin{array}{l}0 \\
0\end{array}$ & $\begin{array}{c}\text { Gran. } \\
0\end{array}$ & $\begin{array}{l}0 \\
0\end{array}$ \\
\hline & 4 & 0 & 0 & 0 & 0 & 0 & 0 \\
\hline & 5 & 0 & 0 & 0 & 0 & 0 & 0 \\
\hline & 6 & Parasite & 0 & 0 & Infl. React. & Gran. & 0 \\
\hline
\end{tabular}

${ }^{1}$ ET: endotoxin (group I); C: controls (group II); Infl. React.: inflammatory reaction around bile ducts; Fat. Inf.: fatty infiltration; Gran.: granuloma; SCN: symmetrical cortical necrosis.

after endotoxin. Abnormal values of other liver enzymes have also been reported $(7,13)$. We observed a significant rise of $5^{\prime}-$ nucleotidase in our study. Alteration of SGOT may result from injury to various tissues, but SGPT and LDH 5 isoenzymes and 5 -nucleotidase are considered specific for hepatic involvement. Lack of elevation of serum bilirubin is not unusual in certain forms of severe liver damage (24). Participation of the liver in the changes that prepare for the Shwartzman reaction has not been recognized but has been attributed to injury of the Kupffer cells (9) which are important elements of the reticuloendothelial system. Others have observed marked hepatic congestion resulting from early hemodynamic changes (12).

Hemostatic disturbances in our animals are more difficult to interpret. A decrease in factors II and V could be due to liver damage or to DIC. Thrombocytopenia is known to result from a direct action of endotoxin on platelets. Factor VIII levels were somewhat lower after endotoxin, but differences were not statistically significant. There was also an increase in split products of fibrinogen in serum, but this was very mild when compared to the changes observed by us (1) in animals that have a full blown Shwartzman reaction (3-6 dilutions greater). It thus appears that the hemostatic abnormalities were the result of a combination of factors, including DIC. Other investigators have failed to find deficits of clotting factors $24 \mathrm{hr}$ after endotoxin administration, although they have observed alterations in coagulation factors similar to ours at $4 \mathrm{hr}(8)$. This may be because other investigators used younger animals weighing $1 \mathrm{~kg}$ and $E$. coli $0127-\mathrm{B} 8$ as the endotoxin preparation, compared to our study in which the animals weighed $2.8-3 \mathrm{~kg}$ and the endotoxin preparation was $E$. coli 0111-B4. In addition, many other factors, such as seasonal and climatic changes, result in considerable variations in tolerance to endotoxin.

The presence of hepatic necrosis in this study was unquestionably due to endotoxin. It was not observed in biopsies before endotoxin administration or in control animals which had not received endotoxin. Similar lesions have been observed by other workers $(11,14,21,30)$, but they have not received sufficient emphasis.

It is known that intravenously injected endotoxin is concentrated in the liver (20). This organ is also responsible for the clearance of thrombi from the circulation (10), an important mechanism in preventing DIC. It is, therefore, reasonable to consider that hepatocellular damage may be an important mechanism in preparation for the Shwartzman reaction. The presence of fibrin thrombi in necrotic areas of the liver suggest early effects of DIC. In rats, such lesions have been prevented by heparinization (21), which again is suggestive of DIC. It appears that early DIC with vascular changes leads to the development of thrombi resulting in areas of necrosis in the liver. These lesions may effect hepatic function and predispose to florid DIC when the second or provocative dose of endotoxin is given.

\section{CONCLUSION}

All 10 rabbits given a single dose of $50 \mu \mathrm{g} / \mathrm{kg}$ gram-negative endotoxin developed abnormalities of liver function after $24 \mathrm{hr}$. All animals had increased LDH isoenzyme 5 and SGOT and decreased serum albumin. A rise in the level of SGPT and $5^{\prime}$ nucleotidase occurred in most rabbits. All of the animals had changes in coagulation tests with decrease in factors II and V and marked thrombocytopenia. There were no significant changes in fibrinogen and factor VIII levels. Split products of fibrinogen showed a slight increase. Definite hepatic necrosis was present in the majority of the animals. The control animals not given endotoxin failed to show evidence of hepatic involvement. These studies indicate that hepatic alterations are prominent after administration of a dose of endotoxin which is considered preparatory for Shwartzman reaction. In view of the role of the liver in replacing consumed clotting factors and clearing thrombi, it is suggested that disturbed liver function plays an important role in predisposing to DIC, which is an intergral part of the Shwartzman reaction.

\section{REFERENCES AND NOTES}

1. Aballi, A. J., Karayalcin, G., Costales, F., and Lanzkowsky, P.: Unpublished observations.

2. Abrams, J. S., Hopkins, R. M., Palmer, R., and Simcone, F. A.: Effect of phenoxibenzamine in endotoxin shock in dogs. II. Metabolic changes. J. Trauma, 9: 614 (1969).

3. Amador, E., and Wacker, W. E. C.: Enzymatic methods used for diagnosis Methods Biochem. Anal., 13: 265 (1957).

4. Belfield, A., Ellis, G., and Goldberg, M.: A specific colorimetric 5'-nucleotidase assay utilizing the Berthelot reactions. Clin. Chem., 165: 396 (1970).

5. Beller, F. K.: The role of endotoxin in disseminated intravascular coagulation. Thromb. Diath. Haemorrh. 36: 125 (1970). 
6. Brecher, G., and Kronkite, E. P.: Morphology and ennumeration of human blood platelets. J. Appl. Physol., 3: 365 (1950).

7. Brown, P. L., and Jeffries, C. D.: Liver glutathione and glutathione reductase response of endotoxin-treated mice. Infect. Immunol., 11: 8 (1975).

8. Corrigan, J. J., Abilgaard, C. F., Vanderheider, J. F., and Schulman, I.: Quantitative aspects of blood coagulation in the generalized Shwartzman reaction. Pediat. Res., 1: 39 (1967)

9. Gans, H.: Mechanism of heparin protection of endotoxin shock. Surgery, 77: $602(1975)$.

10. Gans, H., Stern, R., and Tan, B. H.: Effect of hepatectomy on thrombin clearance. Ann. Surg., 170: 937 (1969).

11. Gerber, J. E.: Pathological aspects of the local and generalized Shwartzman phenomenon. Amer. J. Pathol., 11: 843 (1935).

12. Gilbert, R. P.: Mechanisms of the hemodynamic effects of endotoxin. Physiol Rev., 40: 245 (1961).

13. Griel, L. C., Jr., Zarkower, A., and Eberhart, R. J.: Clinical and clinicopathological effects of Escherichia coli endotoxin in mature cattle. Can. J. Comp. Med., 39: 1 (1975).

14. Hardaway, R. M., Chun, M. B., and Rutherford, R. B.: Histologic evidences of disseminated intravascular coagulation in clinical shock. Vasc. Dis., 2: 254 (1965).

15. Haugier, J., Niewiarowski, S., and Gurewich, V.: Measurement of fibrin degradation products in serum by staphylococcal clumping tests. J. Lab. Clin. Med., 75: 93 (1970).

16. Hodes, H.: Endotoxin shock. Pediatrics, 44: 248 (1969).

17. Hoffman, W. S.: The Biochemistry of Clinical Medicine, Ed. 4 (Year Book Medical Publishers, Inc., Chicago, 1970).

18. Jennings, P. B., Simmons, R. L., Sleeman, H. K., and Hardaway, R. M.: Hemodynamic, biochemical and coagulation changes in endotoxin shock. Ann. Surg., 167: 204 (1968)

19. Langdell, R. D., Wagner, R. H., Brinkhaus, K. M.: Effect of Antihemophilic factor on one stage clotting test: A presumptive test for hemophilia and a one stage antihemophilic factor assay procedure. J. Lab. Clin. Med., 41: 637 (1953).

20. Levy, E., Path, F. C., and Ruebner, B. H.: Hepatic changes produced by a single dose of endotoxin in the mouse: Light microscopy and histochemistry. Amer. J. Pathol., 51: 269 (1967).

0031-3998/78/1205-0646\$02.00/0

Copyright (C) 1978 International Pediatric Research Foundation, Inc.
21. Margaretten, W., McKay, D. G., and Phillips, L. L.: The effect of heparin on endotoxin shock in the rat. Amer. J. Pathol., 51: 61 (1967).

22. McKay, D. G.: Disseminated Intervascular Coagulation (Harper \& Row New York, 1965).

23. Melby, J. C., Egdall, R. H., Bossenmaier, I. C., and Shink, W. W. Suppression by cortisol of increased serum transaminase induced by endotoxin. Lancet, $i: 441$ (1959)

24. Pollack, J. D. (Ed.): Reye's Syndrome (Grune \& Stratton, New York, 1975)

25. Rodostitis, O. M.: The clinical aspect of coliform mastitis in cattle. Proceedings of the Sixth Conference on Cattle Diseases, pp. 67-74 (Heritage Press, Stillwater, OK, 1970).

26. Shapiro, S., Weiner, M., Luddecke, H. F., Korve, R. L., and White, E. T. A simple prepared standardized and relatively stable thromboplastin extract for determination of the prothrombin time. Amer. Heart J., 40: 766 (1950)

27. Sleeman, $H . K$, Jennings, $P, B$, and Hardaway, $R, M$ : Evaluation of biochemical changes associated with experimental endotoxemia. I. Transaminase activity. Surgery, 61: 945 (1967).

28. Stefanini, M., and Damshek, W.: The hemorrhagic disorders, Ed. 2, pp. 496497 (Grune \& Stratton, New York, 1962).

29. Wolff, P. L.: Modification for routine laboratory use of Stafanini's method for estimating factor $\mathrm{V}$ activity in human oxalated plasma. J. Clin. Pathol. 6: 34 (1953)

30. Wong, T. C.: A study of the generalized Shwartzman reaction in pregnant rats induced by bacterial endotoxin. Amer. J. Obstet. Gynecol., 84: 786 (1962).

31. This research was supported by the Long Island Jewish-Hillside Medical Center Research Grant no. 3455828.

32. Appreciation is expressed to Mr. Alfred Adjahoe, Mr. Anthony Zollo, Jr. Mr. Michael Collen, and Mr. Abdul-basir Kazi for their excellent technical assistance, and to Mrs. Frieda Ruderman and Mrs. Ronnie Smith for typing this manuscript.

33. Requests for reprints should be addressed to: Philip Lanzkowsky, M.D., F.R.C.P., D.C.H., Chairman of Department of Pediatrics, Long Island Jewish-Hillside Medical Center, New Hyde Park, NY 11040 (USA).

34. Received for publication November 1, 1976.

35. Accepted for publication July 29, 1977 